\title{
IN-VITRO CULTURE OF RABBIT OVA FROM EARLY CLEAVAGE STAGES TO THE BLASTOCYST STAGE
}

\author{
HIDEO ONUMA, R. R. MAURER AND R. H. FOOTE \\ Department of Animal Science, Cornell University, \\ Ithaca, New York 14850, U.S.A.
}

(Received 26th September 1967, accepted 12th February 1968)

Successful in-vitro culture of fertilized mammalian ova greatly facilitates the study of embryo development. Since Brachet (1912) reported culturing 5-day rabbit blastocysts, considerable effort has been devoted to the development of an in-vitro culture system for rabbit ova. Several investigators have reported culturing 1- and 2-celled rabbit ova to the morula stage, but not to the blastocyst stage (Lewis \& Gregory, 1929; Smith, 1949; Chang, 1950; Purshottam \& Pincus, 1961; Daniel, 1964; Edwards, 1964). The mouse ovum is obstinate in early cleavage stages, but Brinster (1963) recently has successfully cultured 2-celled ova to the hatched blastocyst stage. The peculiar difficulty for the rabbit ova may involve the presence of a relatively tough zona pellucida and mucin coat as pointed out by Pincus (1936).

The present study was initiated to explore the possibility of in-vitro development of rabbit ova from predominantly 2- and 4-cell stages to the blastocyst and hatched blastocyst stages.

Three experiments involving different cultural treatments were conducted: (1) the comparison of rabbit and bovine serum; (2) the addition of $0.05 \%$ glucose to rabbit and bovine serum; (3) a pronase treatment of ova which were cultured in the two serums with and without $0.05 \%$ glucose.

The serums were prepared by allowing whole blood to clot, decanting off the serum, centrifuging at $1485 \mathrm{~g}$ and heating to $56^{\circ} \mathrm{C}$ for $30 \mathrm{~min}$ (Chang, 1949). To each millilitre of serum $0.5 \mathrm{mg}$ streptomycin sulphate and 100 units of penicillin $\mathrm{G}$ were added and the serums were frozen until used. A total of 319 2-cell, 986 4-cell and seventy-nine 8-cell ova was collected from superovulated Dutch-belted does 28 to $32 \mathrm{hr}$ after injection of ovulating hormone. The ova were cultured in $60 \times 15 \mathrm{~mm}$ Falcon tissue culture dishes in $0.2 \mathrm{ml}$ droplets under $10 \mathrm{ml}$ of light paraffin oil at $36^{\circ} \mathrm{C}$ in a humidified mixture of $5 \%$ $\mathrm{CO}_{2}: 95 \%$ air (Brinster, 1963). Each culture dish contained four droplets of media with five to ten ova/droplet.

In Experiment I each culture dish contained two droplets of bovine serum and two of rabbit serum. In Exp. II $5 \mathrm{mg}$ glucose was added to $10 \mathrm{ml}$ of serum. The ova in Exp. III were treated with a $1 \%$ pronase solution for $5 \mathrm{~min}$ at $22^{\circ} \mathrm{C}$ after 52 to $60 \mathrm{hr}$ in culture to weaken the zona pellucida (Edwards, 1964; Cole, Edwards \& Paul, 1966). After treatment with pronase the ova were washed three times and placed in the appropriate fresh medium. 
Ova were examined daily and classified according to stage of development. For summarization and analysis of the data, all ova with less than thirty-two blastomeres were grouped as pre-morula, and those with thirty-two or more blastomeres but without cavity formation as morula. Chi-square and analysis of variance were used to analyse the data.

The most advanced stages of development reached are summarized for the three experiments in Table 1 . Highly significant differences $(P<0 \cdot 005)$ were found in Exp. I between the rabbit and bovine serum. More ova developed to the morula or more advanced stages in the bovine serum than in the rabbit serum; however, significantly $(P<0.005)$ more blastocysts started to hatch in the rabbit serum than in bovine serum.

TABLE 1

DEVELOPMENT OF 2- TO 8-GELL RABBIT OVA IN GULTURE

\begin{tabular}{|c|c|c|c|c|c|c|c|c|c|c|c|}
\hline \multirow{2}{*}{ Treatment } & \multirow{2}{*}{$\begin{array}{l}\text { Total } \\
\text { no. of } \\
\text { ova }\end{array}$} & \multicolumn{2}{|c|}{$\begin{array}{c}\text { Pre- } \\
\text { morula }\end{array}$} & \multicolumn{2}{|c|}{ Morula } & \multicolumn{2}{|c|}{$\begin{array}{c}\text { Blasto- } \\
\text { cysts }\end{array}$} & \multicolumn{2}{|c|}{$\begin{array}{c}\text { Hatching } \\
\text { blasto- } \\
\text { cysts }\end{array}$} & \multicolumn{2}{|c|}{$\begin{array}{c}\text { Hatched } \\
\text { blasto- } \\
\text { cysts }\end{array}$} \\
\hline & & No. & $\%$ & No. & $\%$ & No. & $\%$ & No. & $\%$ & No. & $\%$ \\
\hline $\begin{array}{l}\text { Experiment } I \\
\text { Rabbit serum } \\
\text { Bovine serum }\end{array}$ & $\begin{array}{l}199 \\
147\end{array}$ & $\begin{array}{l}88 \\
16\end{array}$ & $\begin{array}{l}44 \\
11\end{array}$ & $\begin{array}{l}31 \\
41\end{array}$ & $\begin{array}{l}16 \\
28\end{array}$ & $\begin{array}{l}49 \\
82\end{array}$ & $\begin{array}{l}25 \\
56\end{array}$ & $\begin{array}{r}31 \\
8\end{array}$ & $\begin{array}{r}15 \\
5\end{array}$ & $\begin{array}{l}0 \\
0\end{array}$ & \\
\hline $\begin{array}{l}\text { Experiment II } \\
\text { Rabbit serum } \\
\text { Rabbit serum + glucose } \\
\text { Bovine serum } \\
\text { Bovine serum + glucose }\end{array}$ & $\begin{array}{l}189 \\
171 \\
183 \\
187\end{array}$ & $\begin{array}{l}4 \\
5 \\
3 \\
6\end{array}$ & $\begin{array}{l}2 \\
3 \\
2 \\
3\end{array}$ & $\begin{array}{l}21 \\
16 \\
16 \\
11\end{array}$ & $\begin{array}{r}11 \\
9 \\
9 \\
6\end{array}$ & $\begin{array}{r}105 \\
85 \\
111 \\
108\end{array}$ & $\begin{array}{l}56 \\
50 \\
60 \\
58\end{array}$ & $\begin{array}{l}59 \\
63 \\
51 \\
62\end{array}$ & $\begin{array}{l}31 \\
37 \\
28 \\
33\end{array}$ & $\begin{array}{l}0 \\
2^{*} \\
2^{*} \\
0\end{array}$ & $\begin{array}{l}1 \\
1\end{array}$ \\
\hline $\begin{array}{l}\text { Experiment III } \\
\text { Rabbit serum } \\
\text { Rabbit serum + glucose } \\
\text { Rabbit serum + pronase } \\
\text { Rabbit serum + glucose + pronase } \\
\text { Bovine serum } \\
\text { Bovine serum + glucose } \\
\text { Bovine serum + pronase } \\
\text { Bovine serum + glucose + pronase }\end{array}$ & $\begin{array}{l}40 \\
38 \\
35 \\
35 \\
40 \\
45 \\
40 \\
35\end{array}$ & $\begin{array}{l}1 \\
0 \\
0 \\
0 \\
0 \\
4 \\
0 \\
0\end{array}$ & 9 & $\begin{array}{r}10 \\
10 \\
18 \\
14 \\
4 \\
5 \\
13 \\
5\end{array}$ & $\begin{array}{l}25 \\
26 \\
51 \\
40 \\
10 \\
11 \\
32 \\
14\end{array}$ & $\begin{array}{r}17 \\
16 \\
6 \\
2 \\
17 \\
24 \\
9 \\
1\end{array}$ & $\begin{array}{r}42 \\
42 \\
17 \\
6 \\
42 \\
53 \\
22 \\
3\end{array}$ & $\begin{array}{r}12 \\
12 \\
2 \\
2 \\
19 \\
12 \\
2 \\
3\end{array}$ & $\begin{array}{r}30 \\
32 \\
6 \\
6 \\
48 \\
27 \\
6 \\
9\end{array}$ & $\begin{array}{r}0 \\
0 \\
9 \\
17 \\
0 \\
0 \\
16 \\
26\end{array}$ & $\begin{array}{l}26 \\
48\end{array}$ \\
\hline
\end{tabular}

* Droplets were mixed (rabbit serum + glucose and bovine serum) on the 4th day of culture.

The addition of $0.05 \%$ glucose in Exp. II did not increase the number of blastocysts. However, more ova, in general, developed to the blastocyst stage and the difference between the source of serum in promoting blastocyst development found in Exp. I was not found in Exp. II $(P>0 \cdot 05)$, suggesting expected variability in different batches of serum. The transfer of twentyseven blastocysts and three hatching blastocysts cultured for 5 days to uteri of synchronized pseudopregnant and pregnant recipients did not produce any implantations observable 12 days after transfer. Recently Mauer, Hafez, Ehlers \& King (1967) have shown that asynchronous recipients were needed to get ova cultured for $48 \mathrm{hr}$ to implant, since ovum development in vitro is slower than in vivo. The in-vitro rate of development also was slower in the present studies. 
PIATE 1

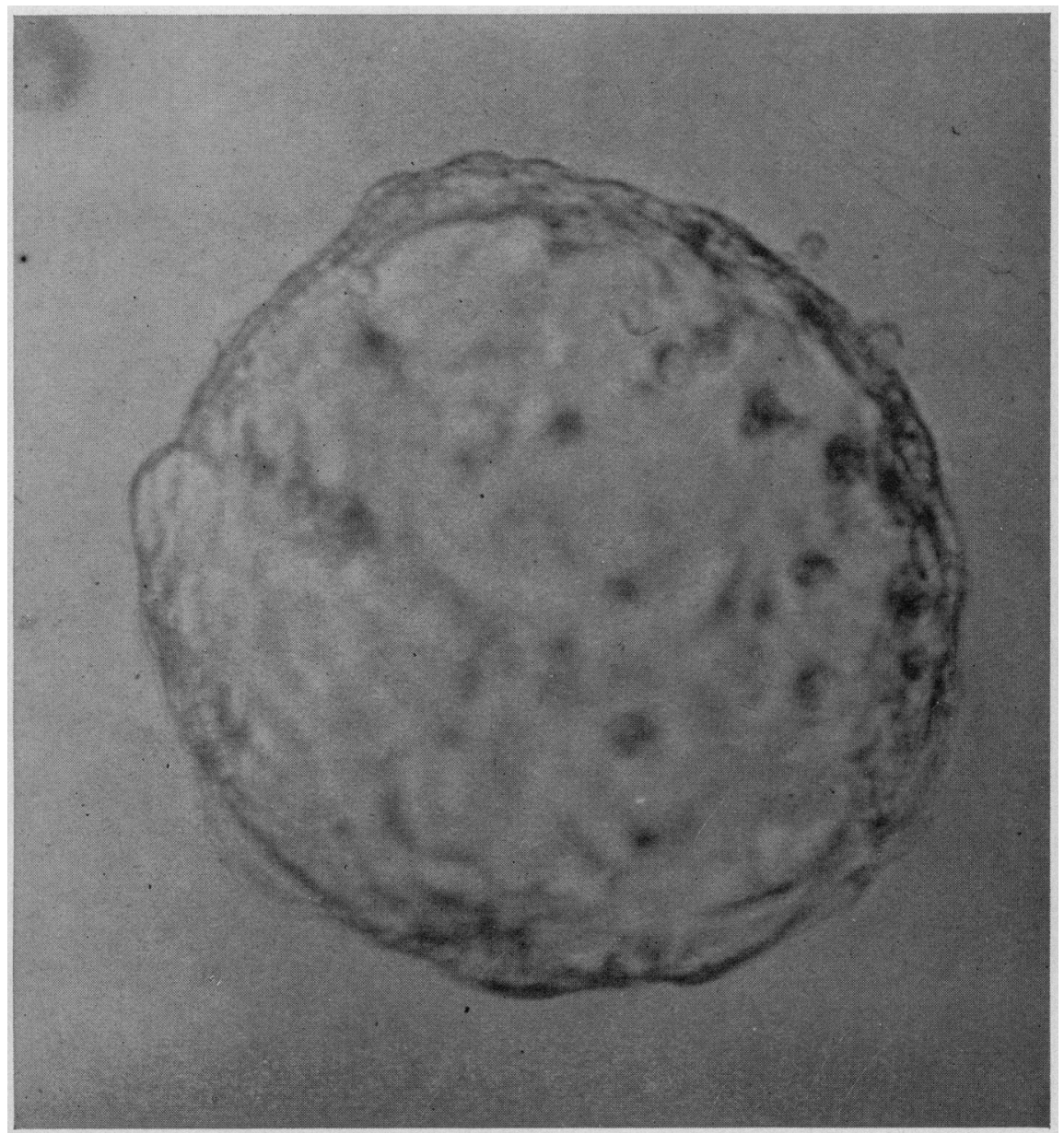

Hatched blastocyst (diameter $300 \mu$ ) cultured from the 4-cell stage for 6 days in bovine serum and treated with pronase for 6 min after 52 to $60 \mathrm{hr}$ in culture. $(\times 313)$.

(Facing p. 492) 
Treating the ova with $1 \%$ pronase solution, in Exp. III, significantly increased $(P<0.001)$ the number of completely hatched blastocysts. The ova hatched from the zona pellucida within $24 \mathrm{hr}$ after pronase treatment. A highly significant $(P<0.001)$ interaction was also found between the addition of glucose and the pronase treatment. The addition of glucose to the media produced more hatched blastocysts when the ova were treated with pronase, but this is not assumed to represent normal hatching. The hatched blastocysts continued to expand for 2 days and the largest hatched blastocysts reached $361 \mu$ in diameter after 6 days in culture (168 hr after LH injections). This size is similar to invivo blastocysts $96 \mathrm{hr}$ post coitum (Adams, 1958). Plate 1 represents a typical 6-day hatched blastocyst. The blastocysts degenerated rapidly 3 days after hatching (Day 7 in culture). No differences $(P>0.05)$ in the number of hatched blastocysts were found between bovine and rabbit serum.

From these results both rabbit and bovine serum are capable of supplying the necessary requirements for 2- and 4-celled rabbit ova to develop into a high proportion of blastocysts. Also, it appears that the combination of weakening the zona pellucida and an additional energy source allowed the developing blastocysts to expand faster resulting in more hatched blastocysts.

This investigation was supported by Public Health Service Research Grant GM 10263 from the National Institute of General Medical Sciences.

\section{REFERENCES}

ADams, C. E. (1958) Egg development in the rabbit: the influence of post-coital ligation of the uterine tube and of ovariectomy. F. Endocr. 16, 283.

Brachet, A. (1912) Development in vitro de blastodermes et de jeunes embryons de mammiferes. C.r. hebd. Séanc. Acad. Sci., Paris, 55, 119.

BRINSTER, R. L. (1963) A method for in vitro cultivation of mouse ova from two-cell to blastocysts. Expl Cell Res. 32, 205.

Chang, M. C. (1949) Effects of heterologous sera on fertilized rabbit ova. F. gen. Physiol. 32, 291.

Chang, M. C. (1950) The effect of seminal plasma on fertilized rabbit ova. Proc. natn. Acad. Sci., U.S.A. 36, 188.

Cole, R. J., Edwards, R. G. \& Paul, J. (1966) Cytodifferentiation and embryo-genesis in cell colonies and tissue cultures derived from ova and blastocysts of the rabbit. Devl Biol. 13, 385.

DANIRL, J. C., JR. (1964) Some effects of steriods on cleavage of rabbit eggs in vitro. Endocrinology, 75, 706.

EDWARDs, R. G. (1964) Cleavage of one- and two-celled rabbit eggs in vitro after removal of the zona pellucida. F. Reprod. Fert. 7, 413.

LeWis, W. H. \& Gregory, P. M. (1929) Moving pictures of developing living rabbit eggs. Anat. Rec. 42, (Suppl.), 27.

MaurR, R. E., Hafez, E. S. E., Ehlers, M. H. \& King, J. R. (1967) Culture of two-cell rabbit embryos in chemically defined media. Expl Cell Res. (In press).

Pincus, G. (1936) The eggs of mammals, p. 160. Macmillan, New York.

Purshottam, N. \& Pincus, G. (1961) In vitro cultivation of mammalian eggs. Anat. Rec. 140, 51.

SMrTH, A. U. (1949) Cultivation of rabbit eggs and cumuli for phase-contrast microscopy. Nature, Lond. $164,1136$. 